\title{
Edukasi Program Prolanis terhadap Asupan Natrium, Kalium dan Serat serta Tekanan Darah pada Pasien Hipertensi di Wilayah Kerja Puskesmas Kuta Alam Banda Aceh
}

\author{
Nunung Sri Mulyani ${ }^{1}$, Fitrah Kurniati ${ }^{1}$, Ardiansyah ${ }^{2}$ \\ ${ }^{1}$ Jurusan Gizi Politeknik Kesehatan Kemenkes Aceh \\ ${ }^{2}$ Rumah Sakit Umum Daerah dr. Zainoel Abidin Banda Aceh \\ Korespondensi E-mail: nunungmulyani76@gmail.com
}

Submitted: 2 April 2021, Revised: 20 Oktober 2021, Accepted: 20 November 2021

\begin{abstract}
Hypertension is one of the factors that increase risk for non-communicable diseases such as heart disease and stroke, so it is necessary to monitor the health of hypertensive patients, one of which is the Chronic Disease Management Program (PROLANIS). The aim of this study is to investigate the influence of Prolanis Program to sodium, potassium and fiber intake and blood pressure in bypertensive patients in the working area of Kuta Alam Health Center, Banda Aceh City. This is cross sectional study that was conducted in February 2019 in the work area of the Kuta Alam Banda Aceh puskesmas. Sampling was done with a total sampling of 35 bypertensive patients. Data collected include sodium intake, potassium and fiber intake using the food recall form and blood pressure data using sphygmomanometer measurements. Data analysis using chi-square statistical tests using univariate and bivariate analysis. There is a relationship between prolanis education on sodium intake in hypertensive patients with p-value $=0.004$, There is a relationship between prolanis education on potassium intake in bypertensive patients with p-value $=0.044$. There is a relationship between prolanis education on fiber intake in bypertensive patients with $P$ $V$ alue $=0.002$ and there is a relationship between prolanis education on blood pressure in bypertensive patients with P V alue $=0.001$. Prolanis education programs affect the intake of sodium, potassium, fiber and blood pressure in hypertensive patients
\end{abstract}

Keyword: bypertension, prolanis, sodium, potassium, fiber

\begin{abstract}
Abstrak
Hipertensi merupakan salah satu faktor yang meningkatkan risiko penyakit tidak menular seperti penyakit jantung dan stroke. Oleh karena itu diperlukan pemantauan kesehatan pasien hipertensi salah satunya dengan Program Pengelolaan Penyakit Kronis (PROLANIS). Tujuan Penelitian ini untuk mengetahui hubungan Program Prolanis terhadap asupan natrium, kalium dan serat serta tekanan darah pada pasien hipertensi di wilayah kerja puskesmas Kuta Alam Kota Banda Aceh. Jenis penelitian ini bersifat deskriptif analitik dengan menggunakan pendekatan cross sectional. Penelitian dilaksanakan pada bulan Februari 2019 di wilayah kerja puskesmas Kuta Alam Banda Aceh. Pengambilan sampel dilakukan dengan total sampling sebanyak 35pasien hipertensi. Data yang dikumpulkan meliputi asupan natrium, asupan kalium dan serat dengan menggunakan lembar food recall dan data tekanan darah menggunakan pengukuran dengan sphygmomanometer. Analisis data menggunakan uji statistik chi-square menggunakan analisa univariat dan bivariat. Ada hubungan antara edukasi program prolanis terhadap asupan natrium pada pasien hipertensi dengan $\mathrm{p}$-value $=0,004$, Ada hubungan antara edukasi program prolanis terhadap asupan kalium pada pasien hipertensi dengan $\mathrm{p}$-value $=0,044$. Ada hubungan antara edukasi program prolanis terhadap asupan serat pada pasien hipertensi dengan p-value $=0,002 \mathrm{dan}$ ada hubungan antara edukasi program prolanis terhadap tekanan darah pada pasien hipertensi dengan $\mathrm{p}$-value $=0,001$. Edukasi program Prolanis mempengaruhi asupan natrium, kalium, serat dan tekanan darah pasien hipertensi.
\end{abstract}

Kata Kunci: hipertensi, prolanis, sodium, kalium, serat

\section{Pendahuluan}

Hipertensi merupakan salah satu faktor penting sebagai pemicu penyakit tidak menular seperti penyakit jantung, stroke dsb (1). Hipertensi dapat terjadi pada setiap orang baik tua maupun muda. Prevalensi hipertensi di Indonesia adalah sebesar 25,8\%. Pada usia 35-44 tahun sebesar 6,3\%, usia 45-54 tahun 11,9\% dan usia 55-64 tahun 17,2\%. Tertinggi di Bangka Belitung sebesar 30,9\% dan yang terendah adalah Papua sebesar 16,8\% (2). Sedangkan hipertensi di Aceh berada pada urutan nomor 27 tertinggi di provinsi Indonsia sebesar 21,5\%. Dengan jumlah kasus pada pasien rawat jalan mencapai 20.667 kasus dan untuk pasien rawat 
inap mencapai 1,963 kasus. Data dari Dinas Kesehatan Aceh tahun 2019 menyatakan bahwa jumlah penderita hipertensi sebesar 1.113. 987 (3).

Gaya hidup diketahui mampu mempengaruhi hipertensi yaitu konsumsi alkohol, konsumsi sodium atau natrium, pola makan, aktivitas fisik dan konsumsi rokok (4). Apabila tidak dikelola dengan baik hipertensi dapat menimbulkan komplikasi seperti stroke, penyakit jantung koroner, gagal jantung, penyakit ginjal kronis, gagal ginjal (5). Pemerintah melalui BPJS Kesehatan mencanangkan Program Pengelolaan Penyakit Kronis (PROLANIS) yang ditujukan pada pasien dengan kasus hipertensi untuk mengatasi kondisi hipertensi pasien. Aktivitas dalam program PROLANIS meliputi aktivitas konsultasi medis atau edukasi, home visit. Tujuan dari kegiatan program pengelolaan penyakit kronis adalah untuk mendorong peserta penyandang penyakit kronis khususnya hipertensi mencapai kualitas hidup optimal dengan indikator $75 \%$ peserta terdaftar yang berkunjung ke fasilitas tingkat pertama memiliki hasil baik pada pemeriksaan spesifik terhadap diabetes mellitus tipe 2 dan hipertensi sesuai panduan klinis sehingga dapat mencegah timbulnya komplikasi penyakit (6).

Dalam mengatasi permasalahan tersebut perlu peran dari berbagai pihak, baik dari tenaga kesehatan yang hendaknya mengupayakan program pengelolaan penyakit kronis tersebut berjalan sehingga dapat mengatasi kasus hipertensi pasien dengan menggunakan metode promotif, preventif, kuratif, dan rehabilitative. Beberapa literature kualitatif menyebutkan bahwa program prolanis masih belum optimal. Banyak tantangan yang harus dihadapi seperti pendanaan, fasilitas pelayanan kesehatan, tidak ada standar operasional prosedur (7). Puskemas Kuta Alam Banda Aceh merupakan salah satu fasilitas kesehatan tingkat pertama mitra BPJS penyelenggara PROLANIS dengan 166 kunjungan hipertensi dari bulan Januari hingga Agustus 2018. Sejauh ini, belum ada penelitian di Puskesmas Kuta Alam Banda Aceh. Untuk itu peneliti tertarik untuk melakukan penelitian mengenai Hubungan Program Prolanis terhadap Asupan Natrium, Kalium, Serat dan Tekanan Darah pada Pasien Hipertensi di Wilayah Kerja Puskesmas Kuta Alam Kota Banda Aceh.

\section{Metode Penelitian}

Penelitian ini bersifat deskriptif analitik dengan desain cross sectional. Penelitian ini dilaksanakan pada bulan Februari 2019 di wilayah kerja puskesmas Kuta Alam Banda Aceh. Populasi yang digunakan dalam penelitian ini adalah seluruh pasien hipertensi sebanyak 35 orang. Data primer meliputi asupan natrium, kalium, serat dengan mewawancarai pasien dengan menggunakan alat bantu 24 hour food recall (8). Pengkategorian data meliputi asupan natrium lebih $(\mathrm{Na}>600 \mathrm{mg})$, asupan natrium cukup $(\leq 600 \mathrm{mg})$, asupan kalium cukup $(\geq 2000 \mathrm{mg}$ ), asupan kalium kurang $(<2000 \mathrm{mg})$. Untuk asupan serat cukup $(\geq 25 \mathrm{gr})$ dan kurang jika asupan (<25 gr) (9). Mengenai edukasi prolanis, pasien ditanyakan keikutsertaannya dengan pilihan jawaban iya dan tidak. Analisis data menggunakan analisis univariat untuk melihat karakteristik umum pasien. Analisis bivariate menggunakan uji korelasi dengan menggunakan analisis statistik uji Cbi-Square.

\section{Hasil dan Pembahasan \\ Karakteristik Sampel Penelitian}

Tabel 1.

Karakteristik Sampel Penelitian di Puskesmas Kuta Alam Banda Aceh Tahun 2019

\begin{tabular}{lcc}
\multicolumn{2}{c}{ Kuta Alam Banda Aceh Tahun 2019 } \\
\cline { 2 - 3 } Variabel & $\mathbf{n}$ Jumlah \\
\hline Jenis Kelamin & & \% \\
$\quad$ Laki-laki & 6 & 17,14 \\
$\quad$ Perempuan & 29 & 82,86 \\
\hline Umur & & \\
$40-50$ & 13 & 37,14 \\
$51-60$ & 22 & 62,86 \\
\hline
\end{tabular}




\begin{tabular}{lcc}
\hline $\begin{array}{l}\text { Pendidikan } \\
\text { Menengah }\end{array}$ & 30 & \\
Tinggi & 5 & 14,29 \\
\hline Pekerjaan & & \\
PNS/Pegawai & 7 & 20 \\
Wiraswasta & 2 & 5,71 \\
Pedagang & 2 & 5,71 \\
IRT & 24 & 68,58 \\
\hline
\end{tabular}

Berdasarkan tabel 1 dapat dilihat bahwa sebagian sampel berjenis kelamin perempuan yaitu 29 orang (82,86\%). Umur pasien sebagian besar berumur 51-60 tahun yaitu sebanyak 22 orang (62,86\%). Pendidikan sampel sebagian besar adalah sekolah menengah yaitu 30 orang (85,71\%) sedangkan pekerjaan sampel sebagian besar adalah ibu rumah tangga yaitu 24 orang $(68,58 \%)$.

\section{Edukasi Program Prolanis dengan Asupan Natrium}

Tabel 2

Hubungan Edukasi Program Prolanis dengan Asupan Natrium, Kalium dan Serat pada Pasien Hipertensi

\begin{tabular}{lccccc}
\hline $\begin{array}{l}\text { Edukasi Program } \\
\text { Prolanis }\end{array}$ & Lebih & Cukup & p-value \\
\hline $\begin{array}{l}\text { Natrium } \\
\text { Pernah }\end{array}$ & 12 & 46,2 & 14 & 53,8 & 0,004 \\
Tidak Pernah & 8 & 88,8 & 1 & 11,1 & \\
\hline Kalium & & & & & 0.04 \\
Pernah & 9 & 34,6 & 17 & 65,4 & \\
Tidak Pernah & 1 & 11,1 & 8 & 88,8 & \\
\hline Serat & 19 & 73,1 & 7 & 26,9 & 0.002 \\
Pernah & 1 & 11,1 & 8 & 42,9 & \\
Tidak Pernah & & & & & \\
\hline
\end{tabular}

Berdasarkan tabel 2 menunjukkan bahwa dari 26 pasien hipertensi yang pernah mendapatkan edukasi program prolanis sebagian besar asupan natriumnya cukup yaitu 14 orang (53,8\%), sedangkan peserta prolanis yang tidak pernah mendapatkan edukasi yaitu sebanyak 8 orang $(88,8 \%)$ asupan natriumnya lebih. Berdasarkan hasil uji dengan menggunakan Chi Square maka diketahui $p$-value $=0,004$, dimana menunjukkan ada hubungan signifikan antara edukasi program prolanis dengan asupan natrium pasien hipertensi. Asupan natrium yang tinggi akan menyebabkan pengeluaran berlebihan hormon natriouretik. Apabila terlalu banyak air keluar dari tubuh, volume darah dan tekanan darah akan turun. Sel-sel ginjal akan mengeluarkan enzim renin. Renin mengaktifkan protein di dalam darah yang dinamakan angiotensinogen ke dalam bentuk aktif berupa angiotensin. Angiotensin akan mengecilkan diameter pembuluh darah sehingga tekanan darah akan naik. Jantung harus memompa keras untuk mendorong volume darah yang meningkat melalui ruang yang makin sempit sehingga menyebabkan hipertensi. Konsumsi garam (natrium) yang tinggi selama bertahuntahun kemungkinan meningkatkan tekanan darah karena meningkatnya kadar sodium di dalam sel-sel otot halus pada dinding arteriol. Garam menyebabkan penumpukan cairan dalam tubuh karena menarik cairan di luar sel agar tidak dikeluarkan, sehingga akan meningkatkan volume dan tekanan darah. Meskipun hasil penelitian kami signifikan, namun beberapa penelitian menunjukkan tidak ada hubungan signifikan antara keikutsertaan program prolanis dengan asupan natrium dan kalium (10-11). 
Sementara itu, untuk asupan kalium menunjukkan bahwa dari 26 pasien hipertensi yang pernah mendapatkan edukasi program prolanis sebagian besar menunjukkan asupan kalium kurang yaitu 17 orang (65,4\%), sedangkan peserta prolanis yang tidak pernah mendapatkan edukasi yaitu sebanyak 8 orang $(88,8 \%)$ asupan kaliumnya kurang. Berdasarkan hasil uji dengan menggunakan Chi Square maka diketahui $p=0,004$, dimana 0,044 $<0,05$ maka ada hubungan antara edukasi program prolanis dengan asupan kalium penderita hipertensi. Konsumsi kalium akan meningkatkan konsentrasi di dalam cairan intraselular, sehingga cenderung menarik cairan dalam ekstraselular dan menurunkan tekanan darah. Kalium adalah mineral yang banyak terdapat dalam sayur dan buah-buahan (12). Kalium dapat menurunkan tekanan darah dengan vasodilatasi sehingga menyebabkan penurunan retensi perifer total dan meningkatkan output jantung. Kalium dapat menurunkan tekanan darah dengan berkhasiat sebagai diuretika yang dapat mengubah aktivitas system reninangiotensin. Keempat, kalium dapat mengatur saraf perifer dan sentral yang mempengaruhi tekanan darah. Berbeda dengan natrium, kalium (potassium) merupakan ion utama di dalam cairan intraseluler. Cara kerja kalium adalah kebalikan dari natrium. Konsumsi kalium yang banyak akan meningkatkan konsentrasinya di dalam cairan intraseluler sehingga cenderung menarik cairan dari bagian ekstraseluler dan menurunkan tekanan darah (13).

Berdasarkan tabel 2 juga menunjukkan bahwa dari 26 pasien hipertensi yang pernah mendapatkan edukasi program prolanis sebagian besar asupan seratnya cukup yaitu 19 orang $(73,1 \%)$, sedangkan yang tidak pernah mendapatkan edukasi sebagian besar asupan seratnya kurang yaitu 8 orang (42,9\%). Berdasarkan hasil uji dengan menggunakan Chi Square maka $p=0,002$, dimana 0,002 $<0,05$ maka ada hubungan antara edukasi program prolanis dengan asupan serat penderita hipertensi. Asupan serat sangat menguntungkan karena dapat mengurangi pemasukan energi dan obesitas yang pada akhirnya menurunkan risiko penyakit tekanan darah tinggi (14). Mengkonsumsi serat 25-30 gram per hari dapat mengikat asam empedu sehingga dapat menurunkan absorbsi lemak dan kolesterol darah, yang nantinya dapat menurunkan risiko tekanan darah tinggi selain itu serat dapat membuat kenyang karena menyerap air dan menurunkan konsumsi energi dengan cara menurunkan konsentrasi lemak dan gula dalam diet yang menyumbangkan sedikit energi, membantu mencegah terjadinya konstipasi, serta kemungkinan menurunkan risiko penyakit jantung karena rendahnya konsentrasi kolesterol dalam batas yang normal (15).

\section{Edukasi Program Prolanis dengan Tekanan Darah}

Tabel 3

Edukasi Prolanis dengan Tekanan darah pada pasien hipertensi di Puskesmas Kuta Alam Banda Aceh Tahun 2019

\begin{tabular}{lccccc}
\hline $\begin{array}{l}\text { Edukasi } \\
\text { Program } \\
\text { Prolanis }\end{array}$ & \multicolumn{4}{c}{ Tekanan Darah } & \\
\hline Pernah & 10 & 38,5 & 16 & 61,5 & \\
Tidak Pernah & 8 & 88,8 & 1 & 11,1 & 0.001 \\
\hline
\end{tabular}

Berdasarkan tabel 3 menunjukkan bahwa dari 26 peserta prolanis yang pernah mendapatkan edukasi program prolanis sebagian besar tekanan darahnya normal yaitu 16 orang $(61,5 \%)$, sedangkan yang tidak pernah mendapatkan edukasi sebagian besar yaitu sebanyak 8 orang $(88,8 \%)$ tekanan darahnya tinggi. Berdasarkan hasil uji dengan menggunakan Chi Square maka diketahui $p=0,001$ dimana 0,001 $<0,05$ maka ada hubungan antara edukasi program prolanis dengan tekanan darah pasien hipertensi. Studi menunjukkan bahwa peserta yang mengikuti program Prolanis memiliki tekanan darah yang lebih rendah bila dibandingkan dengan peserta yang tidak mengikuti kegiatan Prolanis (16).

\section{Kesimpulan}

Edukasi Progaram Prolanis memiliki hubungan yang bermakna dengan asupan natrium, kalium, serat, dan tekanan darah pada pasien hipertensi di wilayah puskesmas Kuta Alam Banda Aceh. Diharapkan bagi pihak puskesmas agar dapat meningkatkan program prolanis sehingga peserta prolanis dapat terus 
memperbaiki status kesehatan terutama pasien dengan tekanan darah tinggi sehingga tekanan darah pasien dapat terkontrol dengan baik.

\section{Daftar Pustaka}

1. Kavishe, B., Biraro, S., Baisley, K., Vanobberghen, F., Kapiga, S., Munderi, P., ... \& Grosskurth H. High prevalence of hypertension and of risk factors for non-communicable diseases (NCDs): a population based cross-sectional survey of NCDS and HIV infection in Northwestern Tanzania and Southern Uganda. BMC Med 13(1), 1-21. 2015;

2. Riskesdas. Laporan Nasional Riskesdas. Kemenkes RI. 2013.

3. Dinas Kesehatan Aceh. Kesehatan Aceh. https://dinkes.acehprov.go.id/uploads/profil_kesehatan_aceh_tahun_2019.pdf

4. Bruno, C. M., Amaradio, M. D., Pricoco, G., Marino, E., \& Bruno F. Lifestyle and hypertension: an evidencebased review. J Hypertens Manag 4(1), 1-10. 2018;

5. Mordi, I., Mordi, N., Delles, C., \& Tzemos N. Endothelial dysfunction in human essential hypertension. J Hypertens 34(8), 1464-1472. 2016;

6. BPJS Kesehatan. Program Pengelolaan Penyakit Kronis [Internet]. Badan Penyelenggaraan Jaminan Kesehatan. 2014. Available from: https://bpjs-kesehatan.go.id/bpjs/dmdocuments/06-PROLANIS.pdf

7. Rachmawati, S., Prihhastuti-Puspitasari, H., \& Zairina E. The implementation of a chronic disease management program (Prolanis) in Indonesia: A literature review. J basic Clin Physiol Pharmacol 30(6). 2019;

8. Gibson, R. S., Charrondiere, U. R., \& Bell W. Measurement errors in dietary assessment using self-reported 24hour recalls in low-income countries and strategies for their prevention. Adv Nutr 8(6), 980-991. 2017;

9. Badan pengembangan dan pemberdayaan sumber daya manusia kesehatan. Dietetika Penyakit Infeksi. Kemenkes RI. 2017.

10. Saparini D. Pengaruh Penyuluhan Tentang Hipertensi Terhadap Tingkat Kecukupan Kalium, Natrium, Cairan dan Tekanan Darah Pada Penderita Hipertensi Peserta Prolanis Bina Sehat di Puskesmas Pringsurat Kabupaten Temanggung. Dr Diss Muhammadiyah Univ Semarang. 2017;

11. Ahmad, D. F. N., \& Siti Zulaekah A. Hubungan Antara Persentase Partisipasi Peserta Dalam Kegiatan Prolanis Dengan Tingat Kecukupan Natrium, Kalium, Dan Magnesium Pasien Hipertensi Di Puskesmas Kota Surakarta. Dr Diss Univ Muhammadiyah Surakarta. 2020;

12. Karyadi. Hidup Bersama Hipertensi, Asam Urat, Jantung Koroner. Jakarta: Intisari Mediatama; 2006.

13. Amran, Y., Febrianti, F., \& Irawanti, L. (2010). Pengaruh tambahan asupan kalium dari diet terhadap penurunan hipertensi sistolik tingkat sedang pada lanjut usia. Kesmas: Jurnal Kesehatan Masyarakat Nasional (National Public Health Journal), 5(3), 125-130.

14. Baliwati, Y.F., Khomsan, A., Dwiriani, C.M. 2004. Pengantar Pangan dan Gizi. Penebar Swadaya. Hal. 89 : Jakarta.

15. Almatsier, S. (2009). Basic principles of nutrition. Jakarta: Gramedia Pustaka Utama.

16. Murti, F. S., Josef, H. K., \& Istiono W. Prolanis Influence on Decreasing Blood Pressure of Hypertension Patients in Puskesmas Pandak II Bantul 2017. Rev Prim Care Pract Educ (Kajian Prakt dan Pendidik Layanan Prim 2(2), 54-59. 2017; 